\title{
Effect of calcium and nitrogen fertilization on bacterial canker susceptibility in stone fruits
}

\author{
Tiesen CAO $^{1^{*}}$, Roger A. DunCAN ${ }^{2}$, Bruce C. KIRKPATRICK ${ }^{3}$, Kenneth A. SHACKEL ${ }^{4}$, Theodore M. DeJONG ${ }^{4}$
}

\author{
${ }^{1}$ Dep. Agric. Food Nutr. Sci., \\ Univ. Alberta, Edmonton, \\ AB T6G 2P5, Canada, \\ tiesen.cao@ualberta.ca \\ 2 Univ. Calif. Coop. Ext., \\ Modesto, CA 95358, USA \\ ${ }^{3}$ Dep. Plant Pathol., Univ. \\ Calif., Davis, CA 95616, USA \\ ${ }^{4}$ Dep. Plant Sci./Pomol., Univ. \\ Calif., Davis, CA 95616, USA
}

${ }^{*}$ Correspondence and reprints

Received 31 July 2012

Accepted 14 September 2012

Fruits, 2013, vol. 68, p. 245-254 (C) 2013 Cirad/EDP Sciences All rights reserved

DOI: $10.1051 /$ fruits/2013071

www.fruits-journal.org

RESUMEN ESPAÑOL, p. 254
Effect of calcium and nitrogen fertilization on bacterial canker susceptibility in stone fruits. Abstract - Introduction. Bacterial canker, caused by Pseudomonas syringae pv. syringae, is a destructive disease where stone fruit trees are cultivated. The efficacy of nitrogen and calcium fertilization on bacterial canker susceptibility was evaluated in stone fruits. Materials and methods. Field experiments were conducted to study the efficacy of foliar applications of calcium nitrate, and ground fertilization with CAN-17 plus low-biuret urea foliar spray on bacterial susceptibility in 'Riegel' peach, 'French' prune and 'Nonpareil' almond growing in ring nematode-infested and nematicide-fumigated soils. Host susceptibility was evaluated by measuring the length of lesions developed following inoculation with $P$. syringae pv. syringae. Results and discussion. Foliar applications of $\mathrm{Ca}\left(\mathrm{NO}_{3}\right)_{2}$ significantly increased leaf nitrogen and bark calcium concentrations in peach trees growing in both fumigated and nonfumigated areas. Peach trees growing in nonfumigated areas developed significantly longer lesions than trees growing in fumigated areas. However, $\mathrm{Ca}\left(\mathrm{NO}_{3}\right)_{2}$ foliar applications had no effect in decreasing peach susceptibility to bacterial infection in both nonfumigated and fumigated areas. After inoculation, diseased prune trees developed significantly longer lesions than healthy trees. Leaf and bark calcium concentrations of diseased prune were significantly increased after $\mathrm{Ca}\left(\mathrm{NO}_{3}\right)_{2}$ foliar sprays, but again the treatments did not significantly affect prune susceptibility to bacterial infection. However, nitrogen fertilization with CAN-17 and urea significantly increased the bark nitrogen concentration of almond trees, and these trees had significantly smaller lesions than those not receiving nitrogen fertilization. Foliar application of calcium (Nutri-Cal) did not affect almond susceptibility to bacterial canker. Collectively, these data support the previous hypothesis that increased susceptibility of stone fruits to P. syringae pv. syringae under nematode infestation conditions is mediated by both nitrogen effects and nitrogenindependent effects, and application of ammonium nitrogen may have some beneficial effects in reducing stone fruit susceptibility to bacterial canker where ring nematode infestation prevails.

USA / Prunus persica / Prunus avium / Prunus domestica / plant diseases / Pseudomonas syringae / plant nematodes / Mesocriconema xenoplax / cultivation Effet de la fertilisation calcique et azotée sur la sensibilité au chancre bactérien des arbres fruitiers à noyau.

Résumé - Introduction. Le chancre bactérien, causé par Pseudomonas syringae pv. syringae, est une maladie destructrice dans les zones où les fruitiers à noyau sont cultivés. L'efficacité de la fertilisation calcique et azotée sur la sensibilité au chancre bactérien a été évaluée pour ces arbres. Matériel et méthodes. Des expériences de terrain ont été réalisées pour étudier l'efficacité d'applications foliaires de nitrate de calcium et de la fertilisation du sol par CAN-17, ainsi que de pulvérisations foliaires d'urée à basse teneur en biuret sur la sensibilité bactérienne du pêcher 'Riegel', du prunier 'français' et de l'amandier 'Nonpareil' développés sur sols infestés de nématodes en anneau ou fumigés par un nématicide. La sensibilité de l'hôte au chancre bactérien a été évaluée par la longueur des lésions développées après inoculation artificielle par la bactérie. Résultats et discussion. Les applications foliaires de $\mathrm{Ca}\left(\mathrm{NO}_{3}\right)_{2}$ ont augmenté significativement les teneurs en calcium des feuilles et en azote de l'écorce pour les pêchers développés soit en zones fumigées, soit en zones non fumigées. Les pêchers en zones non fumigées ont développé des lésions significativement plus longues que les arbres en zones fumigées. Mais les applications foliaires de $\mathrm{Ca}\left(\mathrm{NO}_{3}\right)_{2}$ n'ont pas permis de réduire la sensibilité de l'hôte à l'infection bactérienne pour les pêchers développés sur sols traités ou non traités par fumigation. Après inoculation, les pruniers malades ont développé des lésions significativement plus longues que les pruniers sains. Les concentrations en calcium des feuilles et de l'écorce de pruniers malades ont été significativement augmentées après traitement au $\mathrm{Ca}\left(\mathrm{NO}_{3}\right)_{2}$, mais là encore les traitements n'ont pas eu d'effet significatif sur la sensibilité à l'infection bactérienne du prunier. Cependant, la fertilisation azotée avec CAN-17 et l'urée a significativement augmenté la concentration en azote de l'écorce des amandiers ; ces arbres ont eu des lésions nettement plus petites que ceux ne recevant pas de fertilisation azotée. L'application foliaire de calcium (Nutri-Cal) n'a pas eu d'effet significatif sur la sensibilité des amandiers au chancre bactérien. Globalement, une plus forte sensibilité à $P$. syringae pv. syringae des fruitiers à noyaux en conditions d'infestation de nématodes serait attribuable à la fois à des effets de l'azote et à des effets indépendants de l'azote, et l'application d'azote ammoniacal pourrait être bénéfique pour réduire la sensibilité de ces fruitiers au chancre bactérien là où les infestations par des nématodes en anneau prévallent.

États-Unis / Prunus persica / Prunus avium / Prunus domestica / maladie des plantes / Pseudomonas syringae / nématode des plantes / Mesocriconema xenoplax / pratique culturale 


\section{Introduction}

Bacterial canker, caused by Pseudomonas syringae pv. syringae, is a devastating disease in stone fruit production. According to Cameron, tree losses of $75 \%$ have been observed in young cherry orchards in Oregon when environmental conditions were favorable for bacterial canker development [1] Tree losses of $10 \%$ to $43 \%$ have been reported in young plum orchards due to bacterial canker in Britain [2, 3]. In California tree losses due to bacterial canker caused by $P$. syringae pv. syringae may vary considerably in stone fruit orchards, depending on the population size of ring nematodes in the soil [4-6]. Pseudomonas syringae pv. syringae normally resides as an epiphyte on the surface of trees and causes cankers only when trees have been stressed by various predisposing factors such as coarse soil texture [7], nitrogen deficiency [8-10], water and calcium deficiency [11-13], low soil pH [14], freezing temperatures [15, 16], and high populations of ring nematodes [4-6, 17-20] The most effective measure to control bacterial canker is to suppress the population of ring nematodes by soil fumigation with methyl bromide [21], but the use of methyl bromide as a soil fumigant has been prohibited in the United States because of its deleterious impact on the environment. Therefore, other management strategies need to be identified to reduce losses caused by $P$. syringae pv. syringae.

In California, ring nematode infestation appears to be the most important factor that predisposes stone fruit to bacterial canker. It has been well documented that ring nematode infestation reduces root growth, and causes nitrogen deficiency and water deficit in tree hosts [18, 22, 23]. Nitrogen fertilization has been shown to reduce the severity of bacterial canker in peach and prune $[8$, 10, 19, 20]. Fertilization with balanced nitrogen, phosphorus and potassium fertilizers significantly reduced disease severity in a problem 'French' prune orchard [24]. Increased calcium levels in bark tissues have also been associated with bacterial canker resistance in apricot and peach [11-13]. Previously, supplements of nitrogen for stone fruit trees that have been stressed with nematodes have demonstrated some beneficial effects in reducing peach susceptibility to bacterial canker, although supplements of calcium have no clear effects [19, 20].

In this study, the effects of foliar application of calcium nitrate, and soil fertilization with CAN-17, urea and Nutri-Cal on host susceptibility to $P$. syringae pv. syringae were evaluated in peach, prune and almond trees that were growing in fumigated and nonfumigated sandy soils that contain ring nematodes, in an attempt to test the hypothesis that supplemental application of nitrogen and calcium may compensate for the losses of nitrogen and calcium that may not be taken up as a result of nematode feeding, and thus would decrease the cambium lesions in nematode-infested stone fruits.

\section{Materials and methods}

\subsection{Bacterial strain, inoculation and disease evaluation}

The pathogen used in this research was Pseudomonas syringae pv. syringae strain B3A [25], an ice nucleation-active bacterial strain [26]. For preparation of the inoculum, $P$. syringae pv. syringae was grown in liquid King's medium B [27] at $28^{\circ} \mathrm{C}$ for 2 days with shaking at $180 \mathrm{rpm}$. Two-day-old bacterial culture was centrifuged at $3,000 \times g$ for $7 \mathrm{~min}$ at $4^{\circ} \mathrm{C}$, and the bacterial suspension was obtained by suspending the resultant bacterial pellet in sterile deionized water $\left(\mathrm{sdH}_{2} \mathrm{O}\right)$ to a concentration of approximately $10^{8} \mathrm{CFU} \cdot \mathrm{mL}^{-1}$, as estimated by measuring the optical density at $600 \mathrm{~nm}$. Inoculations were performed on 1-year-old dormant stems of trees growing in peach, prune and almond orchards, respectively, using a pinprick inoculation procedure described previously [28]. Immediately after inoculation, the inoculated site was wrapped with a piece of parafilm to keep it moist, and was allowed to incubate under field conditions for 6 to 8 weeks. Upon the completion of incubation, the size of lesions that were developed in the cambium and inner phloem beneath the inoculation site was 
measured with a digital caliper after the bark was tangentially removed with a razor blade.

\subsection{Foliar application of $\mathrm{Ca}\left(\mathrm{NO}_{3}\right)_{2}$ to peach}

The foliar spray experiment with $\mathrm{Ca}\left(\mathrm{NO}_{3}\right)_{2}$ was conducted in a peach orchard located in the Superior Fruit Ranch near Hughson, CA, USA. The peach trees (Prunus persica (L.) Batsch, cv. Riegel/Nemaguard) used for $\mathrm{Ca}\left(\mathrm{NO}_{3}\right)_{2}$ foliar spray treatments were planted in sandy soil in 1997. Previous peach trees grown in this site had been killed by bacterial canker in 1996 and high populations of ring nematodes (Mesocriconema xenoplax, 442 nematodes per $250 \mathrm{~mL}$ soil) were detected in the soil in June 1996. Preplant soil fumigation was conducted in about 20-m swathes perpendicular to row direction using Enzone (Entek Co., Elkridge, MD), that was applied in April and October 1996, respectively, at a rate of $1400 \mathrm{mg} \cdot \mathrm{L}^{-1}$. In the growing season of 2001, 15 trees each from the fumigated and nonfumigated soils were randomly selected for $\mathrm{Ca}\left(\mathrm{NO}_{3}\right)_{2}$ foliar sprays. An additional 15 trees each, which were randomly selected from the fumigated and nonfumigated areas, were used for nonsprayed controls. There were four rows of trees between the $\mathrm{Ca}\left(\mathrm{NO}_{3}\right)_{2}$ sprayed and nonsprayed trees that were used as a buffer zone. Calcium nitrate $(15.5 \%$ nitrogen, $19 \%$ calcium, Hydro Agri North America, Inc., Redwood City, CA, USA) was dissolved in water to a concentration of $1 \%$, and mixed with $0.05 \%$ Breakthru ${ }^{\circledR}$ (polyether-polymethylsiloxane copolymer) surfactant (Plant Healthy Technologies, Lathrop, CA, USA). Spray application was accomplished using a 120-liter spray tank powered by a gasoline pump. Foliar sprays were applied to runoff with a hand-held sprayer starting from July to September 2001. For each spray, approximately $2 \mathrm{~L}$ of solution were applied to each tree. A total of 3 sprays were applied to trees growing in the nonfumigated area, and 2 sprays were applied to trees in the fumigated area at approximately monthly intervals. Bacterial inoculations were performed on both calcium nitrate-sprayed and nonsprayed trees in January 2002, and lesions were determined 7 weeks after inoculation.

\subsection{Foliar application of $\mathrm{Ca}\left(\mathrm{NO}_{3}\right)_{2}$ to prune}

The prune orchard (Prunus domestica L., cv. French/Mariani 29C) was located near Yuba City, CA, USA. The trees were planted in 1995 and were grown in soils with textures varying from heavy clay to sandy soil. Bacterial canker had been a problem in this orchard for several years, especially in those areas of the orchard with sandy soils. Thirty diseased trees with bacterial canker in a diseased area and 30 healthy trees in a healthy area were randomly selected for the calcium nitrate foliar spray experiment. Fifteen trees each from the diseased and healthy areas were sprayed with $1 \% \mathrm{Ca}\left(\mathrm{NO}_{3}\right)_{2}$ plus $0.05 \%$ Breakthru ${ }^{\circledR}$ surfactant starting from July to September in 2001. The procedure of dilution and application of $\mathrm{Ca}\left(\mathrm{NO}_{3}\right)_{2}$ was essentially the same as described above for calcium nitrate applied to the peach trees. Healthy trees received a total of 2 sprays and diseased trees received 3 sprays during the growing season in 2001. The remaining 15 trees each from the diseased and healthy areas received no application and were used as controls. Bacterial inoculations were made in January 2002 and the lesion length was determined 8 weeks after inoculation.

\subsection{Calcium and nitrogen fertilization experiment on almond}

The almond trees [Prunus dulcis (Mill.) D.A. Webb, cv. Nonpareil] were planted in 1997 and grown in a sandy loam soil near Modesto, CA, USA. Bacterial canker and almond bud drop were the major problems in this orchard and many of the almond trees planted in 1963 were killed by bacterial canker. High populations of ring nematodes were present in the soil. A calcium and nitrogen fertilization trial was established in this orchard in 2000. The nitrogen treatments included ground application of $50.4 \mathrm{~kg} \cdot \mathrm{ha}^{-1}$ (or $0.76 \mathrm{~L} \cdot \mathrm{tree}^{-1}$ ) of CAN-17 (17\% nitrogen, 8.8\% calcium, Chevron Co., Richmond, CA, USA) at monthly intervals 
from May to September in 2000. In addition, foliar applications of low-biuret urea were applied at a rate of $44.8 \mathrm{~kg} \cdot \mathrm{ha}^{-1}$ in July, August and September in 2001, respectively. Calcium treatments included foliar applications of Nutri-Cal (6.5\% nitrogen, 8\% calcium, CSI Co., Bondurant, IA, USA) at a rate of $5.4 \mathrm{~L} \cdot \mathrm{ha}^{-1}$ of the product at monthly intervals from May to September in 2000 and 2001. Ten trees each that were randomly selected from the nitrogen treatment, the calcium treatment and the untreated areas (control) of the orchard were inoculated with $P$. syringae pv. syringae in January 2002. Two inoculations were made on each tree and the inoculated stems were allowed to incubate for 6 weeks under field conditions. The lesion length was determined upon completion of the incubation period, and the average length of the two lesions on each tree was used for statistical analysis.

\subsection{Nitrogen and calcium analysis}

Prior to bacterial inoculation, 1-year-old stems were harvested from those sprayed or fertilized trees for nitrogen and calcium analyses. Stems were soaked in deionized water for about $1 \mathrm{~min}$ and then lightly brushed and rinsed in deionized water About $20 \mathrm{~g}$ of fresh bark were collected by tangentially removing the bark down to the cambium layer. Leaf samples (15 leaves tree $^{-1}$ ), which were collected from the peach and prune orchards in October 2001, respectively, were washed and dried for subsequent nitrogen and calcium analyses. No leaf samples were collected from the almond trees receiving the fertilization treatment. Both bark and leaf samples were dried in an oven for 3 days at $70^{\circ} \mathrm{C}$. Dried bark and leaf samples were ground in a grinder mill (Arthur H. Thomas Co., Laboratory Apparatus, Philadelphia, USA) to pass a 40-mesh sieve. Following the method of Pella [29, 30], total nitrogen was determined by combusting about $3 \mathrm{mg}$ of dried sample wrapped in a tin capsule in an element analyzer (NA 1500, Fisons Instruments, Italy). In addition, (20 to 30) $\mathrm{mg}$ of the dried sample was baked at $500{ }^{\circ} \mathrm{C}$ for $4 \mathrm{~h}$, and the ash was dissolved in $5 \mathrm{~mL} 1 \mathrm{~N} \mathrm{HNO}_{3}$ on a hot plate at $80{ }^{\circ} \mathrm{C}$ for $10 \mathrm{~min}$. The acid extract was filtered through Whatman No. 1 filter paper and the volume was increased to $50 \mathrm{~mL}$ with $\mathrm{sdH}_{2} \mathrm{O}$. Aliquots of this solution were analyzed for calcium using an atomic absorption spectrometer (Analyst 800, Perkin Elmer Instruments, USA).

\subsection{Data analysis}

Data were analyzed for statistical significance using the general linear model (GLM) procedure (Statistical Analysis System; SAS Institute, Cary, NC, USA). Power transformations [31], when appropriate, were applied to the data before subjecting it to statistical analysis. In all cases, both the transformed and original data are presented.

\section{Results}

\subsection{Effect of $\mathrm{Ca}\left(\mathrm{NO}_{3}\right)_{2}$ spray on lesion length and tissue calcium and nitrogen levels in peach}

Analysis of variance of the lesion length data from the peach orchard showed significant effects of soil fumigation, calcium nitrate spray, and the interaction between soil fumigation and calcium nitrate spray (table I). Trees growing in the fumigated area developed significantly smaller lesions than those grown in the nonfumigated area no matter whether the trees received calcium nitrate sprays or not (table II). Unexpectedly, calcium nitrate foliar spray did not decrease lesion length; instead, the lesion lengths were significantly increased, compared with those that did not receive the $\mathrm{Ca}\left(\mathrm{NO}_{3}\right)_{2}$ spray treatment in the nonfumigated area, but had no significant influence on trees growing in the fumigated area (table II), which explained the significant interaction term in this case. The increased variability of the lesion length in calcium nitratetreated trees was due to 3 'outlier' trees among the 15 sprayed trees in the nonfumigated area. These trees developed very large lesions that were (1769.6, 1866.2 and 2035.2) mm long, respectively. These long 
Table I.

Analysis of variance of power-transformed lesion lengths developed after bacterial inoculation in 'Riegel' peach sprayed with calcium nitrate.

$\begin{array}{lccc}\text { Source } & \text { Degree of freedom } & \text { Mean square } & \text { Prob }>\mathrm{F} \\ \text { Soil fumigation }(\mathrm{S})^{\mathrm{a}} & 1 & 0.1074 & <0.0001 \\ \mathrm{Ca}\left(\mathrm{NO}_{3}\right)_{2} \text { spray }(\mathrm{Ca})^{\mathrm{b}} & 1 & 0.0051 & <0.0109 \\ \mathrm{~S} \times \mathrm{Ca}^{\mathrm{c}} & 1 & 0.0133 & <0.0001 \\ \text { Error } & 56 & 0.0007 & \\ \text { a Testing for the effect of preplant soil fumigation. } & \\ \text { b Testing for the effect of foliar spray of } \mathrm{Ca}\left(\mathrm{NO}_{3}\right)_{2} \text {. } & \\ \text { c Testing for the effect of interaction between soil fumigation and calcium nitrate spray. }\end{array}$

\section{Table II.}

Effect of interaction of soil fumigation and foliar spray of $\mathrm{Ca}\left(\mathrm{NO}_{3}\right)_{2}$ on lesion length in 'Riegel' peach (15 replicates per treatment).

$\begin{array}{lccc}\text { Soil fumigation } & \text { Treatment } & \text { Power length } & \text { Lesion length } \\ \text { Fumigation } & \mathrm{Ca}\left(\mathrm{NO}_{3}\right)_{2} \text { spray } & 0.207 \mathrm{a} & 71.1 \pm 7.9 \\ & \mathrm{Control} & 0.195 \mathrm{a} & 78.2 \pm 5.8 \\ \text { Nonfumigation } & \mathrm{Ca}\left(\mathrm{NO}_{3}\right)_{2} \text { spray } & 0.092 \mathrm{c} & 749.2 \pm 160.7 \\ & \text { Control } & 0.141 \mathrm{~b} & 214.1 \pm 37.2\end{array}$

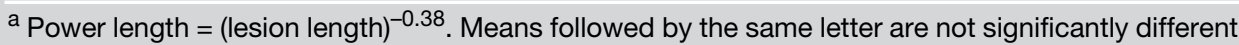
at $P<0.05$ based on Duncan's Multiple Range Test.

${ }^{b}$ Mean of lesion length \pm standard error.

lesions initiated at the inoculated stem and extended to the central trunk of the trees, which were possibly due to some unknown factors other than a pure response to calcium nitrate. The same pattern of significance was obtained when the data were reanalyzed, omitting the 3 'outlier' trees. The mean lesion length was $463.9 \mathrm{~mm}$ and the standard error $61.8 \mathrm{~mm}$ when the 3 'outlier' trees were omitted for the calcium nitrate-treated trees grown in the nonfumigated area. Apparently, a $62 \%$ increase in lesion length due to the 3 'outlier' trees in the same treatment could not be explained by the $\mathrm{Ca}\left(\mathrm{NO}_{3}\right)_{2}$ spray treatment.

Calcium nitrate spray had no effect on bark nitrogen concentration but significantly increased leaf nitrogen and bark calcium concentrations in trees grown in both fumigated and nonfumigated areas (table III). Leaf calcium concentration was significantly increased due to $\mathrm{Ca}\left(\mathrm{NO}_{3}\right)_{2}$ spray in trees grown in the fumigated area but not in the nonfumigated area (table III).

\subsection{Effect of $\mathrm{Ca}\left(\mathrm{NO}_{3}\right)_{2}$ on lesion length and tissue nitrogen and calcium levels in prune}

Analysis of variance revealed that tree health status was the only factor that significantly $(P<0.0001)$ affected lesion length in the prune calcium nitrate foliar spray experiment (data not shown). Diseased trees grown in the diseased area developed significantly longer lesions after bacterial inoculation than the healthy trees grown in the healthy area (table IV). The lesions that developed in calcium nitrate-treated trees were $32 \%$ and $21 \%$ of those in the control in the healthy and diseased areas, respectively, but the difference was not significant (table IV). Tissue nitrogen and calcium analysis indicated that calcium nitrate spray 
Table III.

Effect of foliar spray of $\mathrm{Ca}\left(\mathrm{NO}_{3}\right)_{2}$ on tissue calcium and nitrogen content in 'Riegel' peach (mean \pm standard error).

$\begin{array}{llccc}\text { Soil treatment } & \text { Treatment } & \begin{array}{c}\text { Bark nitrogen } \\ \text { concentration (\%) }\end{array} & \begin{array}{c}\text { Leaf nitrogen } \\ \text { concentration (\%) }\end{array} & \begin{array}{c}\text { Bark calcium } \\ \text { concentration (\%) }\end{array} \\ \text { Fumigation } & \mathrm{Ca}\left(\mathrm{NO}_{3}\right)_{2} \text { spray } & 1.87 \pm 0.04 \mathrm{~b} & 2.26 \pm 0.04 \mathrm{a} & 2.10 \pm 0.12 \mathrm{~b} \\ & \mathrm{Control} & 1.78 \pm 0.03 \mathrm{~b} & 1.81 \pm 0.02 \mathrm{c} & 1.55 \pm 0.09 \mathrm{c} \\ \text { concentration (\%) }\end{array}$

Means followed by the same letter in the same column are not significantly different at $P<0.05$ based on the Duncan's Multiple Range Test.

Table IV.

Effect of foliar spray of $\mathrm{Ca}\left(\mathrm{NO}_{3}\right)_{2}$ on lesion length in 'French' prune trees (15 replicates per treatment).

$\begin{array}{lccc}\text { Tree status } & \text { Treatment } & \text { Power length } & \text { Lesion length }{ }^{\mathrm{b}}(\mathrm{mm}) \\ \text { Healthy } & \mathrm{Ca}\left(\mathrm{NO}_{3}\right)_{2} \text { spray } & 0.327 \mathrm{a} & 11.5 \pm 1.1 \\ & \text { Control } & 0.280 \mathrm{a} & 16.8 \pm 2.8 \\ \text { Diseased } & \mathrm{Ca}\left(\mathrm{NO}_{3}\right)_{2} \text { spray } & 0.228 \mathrm{~b} & 29.4 \pm 5.0 \\ & \text { Control } & 0.213 \mathrm{~b} & 37.0 \pm 6.8\end{array}$

a Power length $=(\text { Lesion length })^{-0.48}$.

Means followed by the same letter are not significantly different at $P<0.05$ based on Duncan's Multiple Range Test.

${ }^{\mathrm{b}}$ Mean \pm standard error.

\section{Table V.}

Effect of foliar spray of $\mathrm{Ca}\left(\mathrm{NO}_{3}\right)_{2}$ on tissue calcium and nitrogen concentrations in 'French' prune trees (mean \pm standard error).

$\begin{array}{lccccc}\text { Tree status } & \text { Treatment } & \begin{array}{c}\text { Bark nitrogen } \\ \text { concentration }(\%)\end{array} & \begin{array}{c}\text { Leaf nitrogen } \\ \text { concentration }(\%)\end{array} & \begin{array}{c}\text { Bark calcium } \\ \text { concentration (\%) }\end{array} & \begin{array}{c}\text { Leaf calcium } \\ \text { concentration (\%) }\end{array} \\ \text { Healthy } & \mathrm{Ca}\left(\mathrm{NO}_{3}\right)_{2} \text { spray } & 1.42 \pm 0.03 \mathrm{a} & 2.04 \pm 0.05 \mathrm{a} & 1.08 \pm 0.03 \mathrm{ab} & 2.21 \pm 0.07 \mathrm{~b} \\ & \mathrm{Control} & 1.45 \pm 0.02 \mathrm{a} & 1.98 \pm 0.05 \mathrm{ab} & 1.13 \pm 0.05 \mathrm{ab} & 2.13 \pm 0.08 \mathrm{~b} \\ \text { Diseased } & \mathrm{Ca}\left(\mathrm{NO}_{3}\right)_{2} \text { spray } & 1.44 \pm 0.05 \mathrm{a} & 1.89 \pm 0.04 \mathrm{bc} & 1.29 \pm 0.09 \mathrm{a} & 2.58 \pm 0.10 \mathrm{a} \\ & \text { Control } & 1.36 \pm 0.04 \mathrm{a} & 1.81 \pm 0.04 \mathrm{c} & 0.96 \pm 0.10 \mathrm{~b} & 2.02 \pm 0.11 \mathrm{~b}\end{array}$

Means followed by the same letter in the same column are not significantly different at $P<0.05$ based on the Duncan's Multiple Range Test.

significantly increased the bark and leaf calcium concentrations only in the diseased trees growing in the diseased area (table $V$ ). Calcium nitrate spray did not have a significant effect on decreasing prune susceptibility to bacterial canker. In addition, calcium nitrate-treated trees growing in the healthy area defoliated in September, which suggests that this treatment may be somewhat phytotoxic.

\subsection{Effect of nitrogen and calcium fertilization on lesion length and bark nitrogen and calcium levels in almond}

Nitrogen-fertilized almond trees developed the smallest lesions among the three treatments (i.e., CAN-17 + Urea spray, NutriCal foliar spray, and nontreated control) 


\begin{tabular}{|c|c|c|c|c|}
\hline \multirow[t]{2}{*}{ Treatment } & \multirow[t]{2}{*}{$\begin{array}{l}\text { Power } \\
\text { length }^{a}\end{array}$} & $\begin{array}{l}\text { Lesion length } \\
\qquad(\mathrm{mm})\end{array}$ & $\begin{array}{c}\text { Bark nitrogen } \\
\text { concentration (\%) }\end{array}$ & $\begin{array}{l}\text { Bark calcium concentration } \\
(\%)\end{array}$ \\
\hline & & \multicolumn{3}{|c|}{ Mean \pm standard error } \\
\hline CAN-17 + urea spray & $0.791 \mathrm{a}$ & $15.3 \pm 2.6$ & $1.66 \pm 0.04 a$ & $0.75 \pm 0.05 a$ \\
\hline Nutri-Cal spray (Ca) & $0.739 \mathrm{~b}$ & $35.3 \pm 6.2$ & $1.47 \pm 0.05 b$ & $0.69 \pm 0.05 a$ \\
\hline Control & $0.731 \mathrm{~b}$ & $40.9 \pm 7.6$ & $1.38 \pm 0.04 b$ & $0.72 \pm 0.06 \mathrm{a}$ \\
\hline
\end{tabular}

following bacterial inoculation (table VT). Nitrogen fertilization significantly increased the bark nitrogen concentration, but calcium spray treatment did not have a significant effect on bark calcium concentration (table VI).

\section{Discussion}

Calcium nitrate foliar spray significantly increased leaf nitrogen and bark calcium concentrations in peach trees grown in both fumigated and nonfumigated soils. However, calcium nitrate sprays did not reduce bacterial canker susceptibility to $P$. syringae pv. syringae; instead, lesions were significantly increased in trees that were growing in the nonfumigated area compared with trees that did not receive the treatments. The lesions that developed in calcium nitratetreated trees growing in the nonfumigated area were more variable in size compared with lesions in the trees growing in the same area without this treatment. The increased variability in lesions was not solely a response to the calcium nitrate treatment because calcium nitrate spray did not significantly influence the disease severity in trees that were growing in the fumigated area. The data cannot explain why the 3 'outlier' trees developed larger lesions than the rest of the trees in the same treatment. The results obtained from peach trees sprayed with calcium nitrate are not consistent with the previous results that nitrogen fertilization reduces bacterial canker severity in peach [8], nor are these results in agreement with previous reports that lesion length was negatively correlated with bark calcium concentration in apricot [13] and peach [11, 12]. However, the Vigouroux and Bussi studies were conducted in acidic soils $[12,13]$ while the soils in our study were close to neutral. This difference in soil $\mathrm{pH}$ may account for the different disease responses to applied calcium. In addition, Wormald and Garner reported that fertilization with nitrogen, phosphate and potassium alone or in combination did not have any significant effect on bacterial canker severity in plum, and adding lime to the soil increased plum susceptibility to bacterial canker [32]. Similarly, applications of lime to sandy soils with high populations of ring nematodes failed to reduce the incidence of bacterial canker in peach trees [6, 8, 33]. Obviously, these reports are not consistent with the assumption of the beneficial effect of calcium for reducing bacterial canker susceptibility in stone fruits.

Foliar application of calcium nitrate significantly increased leaf and bark calcium concentrations in prune trees affected by bacterial canker. Calcium nitrate treatment had no significant effect on reducing lesion length in prune trees, although there was a trend that trees with calcium nitrate sprays had smaller lesions than those without the treatment for both the healthy and diseased trees. Previous studies showed that fertilization with urea (UN-32) decreased bacterial canker incidence in 'French' prune [10] and 
peach $[19,20]$, and fertilization with nitrogen, phosphorus and potassium (16-16-16) containing micronutrients significantly decreased the severity of bacterial canker [24]. The current study demonstrated that calcium nitrate spray had no significant effect on reducing bacterial canker susceptibility in 'French' prune. In addition, we noticed a slightly earlier defoliation in late September in calcium nitrate-treated prune trees. This may have been the result of minor phytotoxicity associated with the calcium treatment, which suggests a concentration lower than $1 \%$ of calcium nitrate should be used to ensure normal defoliation in 'French' prune.

Foliar application of urea combined with soil application of CAN-17 significantly increased the bark total nitrogen concentration in 'Nonpareil' almond, but foliar application of Nutri-Cal did not significantly increase the bark calcium concentration. Fertilization with urea and CAN-17 significantly reduced almond tree susceptibility to bacterial canker as determined by lesion length, but Nutri-Cal did not have a significant effect on decreasing disease severity in almond. The significant effect of nitrogen fertilization on reducing bacterial canker severity in almond is in agreement with the results obtained in 'French' prune [10, 24] and peach [19, 20]. However, we did not find significant beneficial effects of nitrogen fertilization in 'Riegel' peach or 'French' prune.

Urea is an ammonium nitrogen fertilizer, and CAN-17 contains $5.4 \%$ ammonium nitrogen. Compared with calcium nitrate, combined application of CAN-17 and urea foliar spray may contain a relatively high proportion of ammonium nitrogen. Nitrogen fertilization with CAN-17 has previously been reported to reduce bacterial canker in 'French' prune [10] and peach [19, 20]. Ammonia-generating fertilizers were reported to have an effect in reducing ring nematode populations in soil [34] and this effect may be related to decreased severity of bacterial canker. Additional research is needed to determine whether fertilization with ammonium nitrogen decreases bacterial canker susceptibility by reducing ring nematode populations in the soil or directly by enhancing tree growth and vigor.
In summary, calcium nitrate foliar spray significantly increased leaf nitrogen and bark calcium concentrations in peach grown in both fumigated and nonfumigated soils, and leaf and bark calcium concentrations in diseased 'French' prune trees, but it did not have a significant effect on reducing bacterial canker severity in 'Riegel' peach or 'French' prune. Nitrogen fertilization with urea foliar spray and CAN-17 significantly increased the bark nitrogen concentration and decreased stem susceptibility to bacterial canker in almond. The results of this study are consistent with the previous hypothesis that increased susceptibility of peach to $P$. syringae pv. syringae under nematode infestation conditions is mediated by both nitrogen effects and nitrogen-independent effects $[19,20]$, but are not in agreement with the previous reports of the beneficial effects of calcium for reducing bacterial canker [11-13].

\section{Acknowledgments}

The author thanks Chad Vargas for assistance in field trials, and Shoi Farms, Superior Fruit Ranch and Roger Soderstrom for providing experimental trees for this research. This research was supported by The California Prune, Cling Peach and Almond Boards.

\section{References}

[1] Cameron H.R., Diseases of deciduous fruit trees incited by Pseudomonas syringae van Hall. A review of the literature with additional data, Oregon Agric. Exp. Stn. Tech. Bull. 66 (1962) 1-64.

[2] Wormald H., Bacterial diseases of stone fruits in Britain. III. The symptoms of bacterial canker in plum trees, J. Pomol. 9 (1931) 239-256.

[3] Wormald H., Bacterial canker as a cause of dieback in plum trees, J. Minist. Agric. 39 (1932) 208-217.

[4] English H., Lownsbery B.F., Schick F.J., Burlando T., Effect of ring and pin nematodes on the development of bacterial canker and Cytospora canker in young 
'French' prune trees, Plant Dis. 66 (1982) 114-116.

[5] McKenry M.V., Kretsch J., Survey of nematodes associated with almond production in California, Plant Dis. 71 (1987) 71-73.

[6] Underwood T., Jaffee B.A., Verdegaal P., Norton M.V.K., Asai W.K., Muldoon A.E. McKenry M.V., Ferris H., Effect of lime on Criconemella xenoplax and bacterial canker in two California orchards, J. Nematol. 26 (1994) 606-611.

[7] Vigouroux A., Bussi C., Une action possible des sols sur la prédisposition des pêchers au dépérissement bactérien par modification de la teneur en eau hivernale des tiges, Agronomie 14 (1994) 319-326.

[8] English H., DeVay J.E., Lilleland O., Davis J.R., Effect of certain soil treatments on the development of bacterial canker in peach trees, (Abstr.) Phytopathology 51 (1961) 65.

[9] Melakeberhan H., Jones A.L., Sobiczewsk P., Bird G.W., Factors associated with the decline of sweet cherry trees in Michigan: nematodes, bacterial canker, nutrition, soil $\mathrm{pH}$, and winter injury, Plant Dis. 77 (1993) 266-271.

[10] Southwick S.M., Yeager J.T., Weis K.G., Kirkpatrick B.C., Little E.L., Westerdah B.B., Relationship between nitrogen fertilization and bacterial canker in 'French' prune, (Abstr.) HortSci. 32 (1997) 520.

[11] Vigouroux A., Berger J.F., Bussi C., La sensibilité du pêcher au dépérissement bactérien en France : incidence de certaines caractéristiques du sol et de l'irrigation. Relations avec la nutrition, Agronomie 7 (1987) 483495.

[12] Vigouroux A., Bussi C., Importance of water consumption on calcium content and protection of peaches predisposed to bacterial dieback by growing in acid soils, Acta Hortic. 254 (1989) 291-296.

[13] Vigouroux A., Bussi C., Influence of water availability and soil calcic amendment on susceptibility of apricot to bacterial canker, Acta Hortic. 384 (1995) 607-611.

[14] Weaver D.J., Wehunt E.J., Effect of soil pH on susceptibility of peach to Pseudomonas syringae, Phytopathology 65 (1975) 984989.

[15] Klement Z., Rozsnyay D.S., Arsenijevic M., Apoplexy of apricots. II. Relationship of winter frost and the bacterial canker and dieback of apricots, Acta Phytopathol. Acad. Sci. Hung. 9 (1974) 35-45.
[16] Weaver D.J., Interaction of Pseudomonas syringae and freezing in bacterial canker on excised peach twigs, Phytopathology 68 (1978) 1460-1463.

[17] Weaver D.J., Wehunt E.J., Dowler W.M., Association of tree site, Pseudomonas syringae, Criconemoides xenoplax, and pruning date with short life of peach trees in Georgia, Plant Dis. Rep. 58 (1974) 76-79.

[18] Mojtahedi H., Lownsbery B.F., Moody E.H., Ring nematodes increase development of bacterial cankers in plums, Phytopathology 65 (1975) 556-559.

[19] Cao T., Duncan R.A., McKenry M.V., Shackel K.A., DeJong T.M., Kirkpatrick B.C., The interaction between nitrogen fertilized peach trees and the expression of syrB, a gene involved in syringomycin production in Pseudomonas syringae pv. syringae, Phytopathology 95 (2005) 581-586.

[20] Cao T., McKenry M.V., Duncan R.A., DeJong T.M., Kirkpatrick B.C., Shackel, K.A., Influence of ring nematode infestation and calcium, nitrogen, and indoleacetic acid applications on peach susceptibility to $P$ seudomonas syringae pv. syringae, Phytopathology 96 (2006) 608-615.

[21] English H., DeVay J.E., Schick F.J., Lownsbery B.F., Reducing bacterial cankerdamage in 'French' prunes, Calif. Agric. 37 (1983) 10-11.

[22] Mojtahedi H., Lownsbery B.F., Pathogenicity of Criconemoides xenoplax to prune and plum rootstocks, J. Nematol. 72 (1975) 114119.

[23] Sharpe R.R., Nyczepir A.P., Reilly C.C., Effect of nematodes on nutrient uptake in Lovell and Nemaguard peach seedlings, in: Zehr E.D. (Ed.), Stone Fruit Tree Decline, Third Workshop Proc., USDA-ARS, Beltsville, MD, U.S.A., 1988, pp. 46-83.

[24] Sayler R.J., Kirkpatrick B.C., The effect of copper sprays and fertilization on bacterial canker in 'French' prune, Can. J. Plant Pathol. 25 (2003) 406-410.

[25] DeVay J.E., Lukezic F.L., Sinden S.L., English H., Coplin D.L., A biocide produced by pathogenic isolates of Pseudomonas syringae and its possible role in the bacterial canker disease of peach trees, Phytopathology 58 (1968) 95-101.

[26] Cao T., Kirkpatrick B.C., Shackel K.A., DeJong T.M., Influence of mineral nutrients and freezing-thawing on peach susceptibility to bacterial canker caused by Pseudomonas 
syringae pv. syringae, Fruits 66 (2011) 441452.

[27] King E.O., Ward M.K., Raney D.E., Two simple media for the demonstration of pyocyanin and fluorescin, J. Lab. Clin. Med. 44 (1954) 301-307.

[28] Cao T., Sayler R.J., DeJong T.M., Kirkpatrick B.C., Bostock R.M., Shackel K.A., Influence of stem diameter, water content and freezing-thawing on bacterial canker development in excised stems of dormant stone fruit, Phytopathology 89 (1999) 962-966.

[29] Pella E., Elemental organic analysis. Part 1. Historical developments, Am. Lab. 22 (1990) 116-125.

[30] Pella E., Elemental organic analysis. Part 2. State of the art, Am. Lab. 22 (1990) 28- 32.
[31] Fernandez G.C.J., Residual analysis and data transformations: Important tools in statistical analysis, HortScience 27 (1992) 297300.

[32] Wormald H., Garner R.J., Manurial trial on nursery trees with reference to effect on plum bacterial canker, Annu. Rep. East Malling Res. Stn. 1937. Sect. III, 1938, pp. 194-197.

[33] Wehunt E.J., Weaver D.J., Effect of high rates of calcium and magnesium soil amendments on Macroposthonia xenoplax and bacterial canker of peach seedlings, J. Nematol. 12 (1980) 240-241.

[34] Mojtahedi H., Lownsbery B.F., The effects of ammonia-generating fertilizer on Criconemoides xenoplax in pot cultures, J. Nematol. 8 (1976) 306-309.

\section{Efecto de la fertilización cálcica y nitrogenada en la sensibilidad al cancro bacteriano de los árboles frutales de hueso.}

Resumen - Introducción. El cancro bacteriano, causado por Pseudomonas syringae pv. syringae, es una enfermedad destructora en las zonas donde se cultivan frutales de hueso. Se evaluó el efecto de la fertilización clásica y nitrogenada en la sensibilidad al cancro bacteriano en dichos árboles. Material y métodos. Se realizaron experimentos sobre el terreno para estudiar la eficacia tanto de las aplicaciones foliares de nitrato de calcio y de la fertilización del suelo con CAN-17, como de las pulverizaciones foliares con urea de bajo contenido en biuret en la sensibilidad bacteriana del melocotonero 'Riegel', del ciruelo 'francés' y del almendro 'Nonpareil' desarrollados en suelos infestados de nematodos redondos o fumigados con un nematicida. La sensibilidad del huésped al cancro bacteriano se evaluó por la duración de las lesiones desarrolladas tras la inoculación artificial de la bacteria. Resultados y discusión. Las aplicaciones foliares de $\mathrm{Ca}\left(\mathrm{NO}_{3}\right)_{2}$ aumentaron significativamente el contenido en calcio de las hojas y el contenido en nitrógeno de la corteza en los melocotoneros desarrollados tanto en zonas fumigadas como no fumigadas. Los melocotoneros de zonas no fumigadas desarrollaron lesiones significativamente más largas que los árboles de zonas fumigadas. Sin embargo, las aplicaciones foliares de $\mathrm{Ca}\left(\mathrm{NO}_{3}\right)_{2}$ no permitieron reducir la sensibilidad del huésped a la infección bacteriana en los melocotoneros, desarrollados en suelos tratados o no mediante fumigación. Tras la inoculación, los ciruelos enfermos desarrollaron lesiones significativamente más largas que los ciruelos sanos. Las concentraciones de calcio en las hojas y en la corteza de los ciruelos enfermos aumentaron significativamente tras el tratamiento con $\mathrm{Ca}\left(\mathrm{NO}_{3}\right)_{2}$, pero, de nuevo, los tratamientos no tuvieron un efecto significativo en la sensibilidad a la infección bacteriana del ciruelo. Sin embargo, la fertilización nitrogenada con CAN-17 y urea aumentó significativamente la concentración de nitrógeno en la corteza de los almendros: estos árboles presentaron lesiones claramente más reducidas que los que no recibieron fertilización nitrogenada. La aplicación foliar de calcio (Nutri-Cal) no tuvo un efecto significativo en la sensibilidad de los almendros al cancro bacteriano. En general, la mayor sensibilidad a $P$. syringae pv. syringae por parte de los frutales de hueso en condiciones de infestación por nematodos podría atribuirse tanto a los efectos del nitrógeno como a otros efectos independientes del nitrógeno, y la aplicación del nitrógeno amoniacial podría ser beneficiosa para reducir la sensibilidad de dichos frutales al cancro bacteriano cuando prevalecen las infestaciones por nematodos circulares.

EUA / Prunus persica / Prunus avium / Prunus domestica / enfermedades de las plantas / Pseudomonas syringae / nematodos de las plantas / Mesocriconema xenoplax / cultivo 